\title{
International Tax Planning: Current State of Knowledge
}

\author{
Vit Jedlička*
}

\begin{abstract}
:
Globalisation affects the behaviour of managers of companies and brings many new possibilities in management. These changes affect activities related to tax optimization and they can be collectively called as international tax planning. This paper monitors current situation of tax planning activities and its aim is to present a current state of knowledge. It contains data showing high frequency of tax planning activities. There are briefly outlined ways of international tax optimization and attitude of organisations to the tax planning of multinationals corporations. Significant part of this paper is devoted to the overview of literature, which deals with measuring international tax optimization. There are several attitudes in selected studies that can be also used (with adaptation to the different data) for monitoring of situation in the Czech Republic. Overall, the most attitudes use applications of effective tax rate and this rate, which is for every country and corporation different, is a key factor for tax planning decision-making.
\end{abstract}

Key words: International tax planning; Tax optimization; Profit shifting.

JEL classification: H25, M29.

\section{Introduction}

Tax optimization is a group of activities, which leads to reduction of tax costs. Companies use tax optimization to increase the amount of funds, which can be used according to the needs of the company by several ways. Activity called tax planning has become more frequently used term than tax optimization. OECD (2017) defines tax planning as "arrangement of a person's business and /or private affairs in order to minimize tax liability." New technologies bring uncomplicated ways for managers of companies to benefit from multiple legislations of different countries via subsidiaries. When it comes to this international dimension, activity of corporation is called international tax planning. Some countries, which can be called tax havens, benefits from these trends and try to attract the largest possible number of companies. They use for it several policies including lower tax rate on selected income, special tax regimes, anonymity of owners or simpler accounting obligations (Gravelle, 2015; Bennedsen and Zeume, 2015). These activities lead to tax competition between countries because every government wants to gain foreign investment (Wiebe, 2011). There are few other terms connected with tax planning. Tax avoidance is understood as completely

Vít Jedlička; University of Pardubice, Faculty of Economics and Administration, Institute of Business Economics and Management, Studentská 95, 53210 Pardubice, Czech Republic, <vit.jedlicka@student.upce.cz>. 
legal activity consisting in the use of all available tax deductions, tax credits and other legal benefits to minimize own tax liability (Gravelle, 2015). On the other hand, tax evasion usually stands for an illegal activity because the taxpayer does not give right information about his taxable income but the boundary between tax avoidance and tax evasion "is not entirely clear." (Gravelle, 2015) Issue of tax evasions is actual all around the world and each affected country has its own policy of facing this problem.

The goal of this paper is to present the topic of international tax planning and current state of knowledge related to it focusing on studies of measuring of tax planning activities and measuring of benefits for corporation using tax planning. The second part of this paper includes selected studies which confirm the fact, that tax planning is an important topic. This section is dedicated to demonstration of the importance of this topic. There are studies, which provide identification of countries, which can be considered as tax haven in this part, followed by activities of international organizations affecting tax planning. At the end of the second part there are briefly specified major tax planning activities. Third part of this paper is focused on studies, which quantify corporations' tax planning activities and benefits from them. The final part of this paper is dedicated to conclusions based on selected literature.

\section{Vastness of Tax Planning}

View on tax planning and tax havens differs from one country to another. Government of the country, which others consider as tax haven, usually does not act against tax planning. On the other hand, countries, which have lower tax revenues due to tax havens, tend to apply legislation against using of tax havens. Tax havens and their usage are often discussed also in the Czech Republic. Even though the Czech Republic is relatively small country with only few international companies, tax planning and profit transferring to tax havens are common.

Total amount of Czech companies using tax havens was increasing in recent years but there was an outflow from tax havens in 2016, according to data from Bisnode (Bisnode, 2016). The most attractive tax haven for Czech companies is the Netherlands, which is also popular tax haven for companies from other EU countries and for American companies. There are about 4,000 Czech companies with headquarter in Netherlands (Bisnode, 2016). Data from this company provides one unexpected information that Bisnode considers USA to be a tax haven for Czech companies with about 3,000 of them based in this country (Bisnode, 2016). The USA itself is engaged in the fight against tax havens but for other countries it belongs to them. This situation only demonstrates problematic identification of tax havens. Every company has different needs and different 
structure of revenues and costs, so their requirements for tax legislation diverge. From the first view, small islands can be considered as less attractive from the perspective of Czech corporations according to Bisnode data (Bisnode, 2016). On the other hand, absolute numbers cannot provide data to comparison because they do not reflect the size of country and size of economy.

Press and experts also deal with a problem of tax planning in their studies; they demonstrate effects of this behaviour of companies. Dutch newspapers Volskrant dealt with using Netherlands as tax haven in 2013 (VK Data, 2013). Their experts have analysed data from the year before and they have focused on the amount of money, which is artificially transferred to Netherlands. Companies from all around the world use Dutch tax system through "a web of letterbox companies to make best use of the tax advantages that the Netherlands may provide." (VK Data, 2013) They are called letterbox firms because of their low number of employees (usually they have no staff) (VK Data, 2013). Global companies also use other types of legal entities to manage the sum of taxes (not only typical companies but co-operatives or foundations too) (VK Data, 2013).

Identified data from Netherlands demonstrate that through this tax haven flows a huge amount of money, which, of course, is not generated by Dutch subjects. For the concrete amounts of money: Google, Inc. transferred to the Netherlands over 7 billion euros; IBM, Eni, HSBC and BP less than five billion euros (VK Data, 2013). These large sums of money prove the fact that tax havens are not only frequently used (by many companies) but also used for a large part of sales.

There are lot of institutions all around the world, which deal with usage of tax havens; e.g. American Congressional Research Service (Gravelle, 2015), OECD (2017) or European Union (European Commission, 2016). Especially government institutions of affected countries focus on negative aspect of tax planning, which, of course, is related to the government's view on the issue of tax planning. On the other hand, there are also institution with independent character, which are interested in topic of taxation or international corporations, which provide services in tax planning. Finally, yet importantly, there are individual experts from universities whose view is not influenced by business interests in this field, so they can provide a more objective approach. Essentially, studies from academics consider both perspectives, so they conclusions should be more accurate.

Above-mentioned tax competition is another important concept related to tax planning. Tax competition is basically connected with governments and their legislation, not with companies. Multinational corporations only benefit from competition in tax legislation. From the perspective of OECD globalization "had the negative effects of opening up new ways by which companies and individuals can minimise and avoid taxes and in which countries can exploit these new 
opportunities by developing tax policies aimed primarily at diverting financial and other geographically mobile capital." (OECD, 1998) These sentences provide one important information, which is key in understanding of approach of OECD. Its view on tax competition is negative, so like the view of all important OECD members like USA, Germany or France, which all belong to the biggest economies in the world.

Attitude of OECD to tax havens is important for the development of tax planning. This organization integrates mainly high developed countries but its activities in tax planning have global impact. OECD "brings together over 100 countries and jurisdictions to collaborate on the implementation of the OECD/ G20 Base Erosion and Profit Shifting (BEPS) Package." (OECD, 2017) BEPS package is directed against "tax avoidance, ensuring that profits are taxed where economic activities generating the profits are performed and where value is created." (OECD, 2017) This politics has potential to change international tax planning because of wide range of participating countries. Activities integrated in BEPS package are reaction on tax planning techniques of international companies. BEPS package is designed as complex of specific actions in particular sections (OECD, 2017). According to OECD strategy special attention is given to transfer pricing, which belongs to popular techniques in international tax optimization because OECD set three actions related to transfer pricing (OECD, 2017). Other topics, which are significant for OECD, are for example profit shifting of controlled foreign corporations, transparency in special regimes (IP box) or multilateral attitude to coordination of international taxation (not only bilateral tax treaties) (OECD, 2017).

There are also many other documents related to tax planning, Foreign Account Tax Compliance Act (FACTA) belongs to them (Lunder and Pettit, 2016). "FATCA is intended to curb U.S. tax evasion occurring through the use of offshore accounts." (Lunder and Pettit, 2016) There are two key features of this act: US taxpayers have to "report assets held in overseas accounts" and "it requires foreign financial institutions to disclose financial information" related to mentioned taxpayers (Pomerleau, 2014). All that means that it requires group of bilateral agreements with other countries (Pomerleau, 2014). This law has international dimension for one another reason: because it requires information from all US taxpayers, it affects also taxpayers from other countries if they have economical activities in USA. If taxpayers or financial institutions do not cooperate, they face penalties (Pomerleau, 2014).

Laura Vartia from OECD has dealt with connection between taxation conditions and investments (Vartia, 2008). She mentions within conclusions that reduction in a tax rate on corporate income has a positive effect on the amount of investment in the country (Vartia, 2008). This conclusion has significant impact on problematics 
of tax havens because their taxation policy entices and convinces corporations to invest in these countries.

When the tax competition is mentioned, one important question should be formulated: how the tax competition can be measured if it ever can be. American research institute Tax Foundation deals with tax competition from the perspective of tax competitiveness of countries. Their International Tax Competitiveness Index "seeks to measure the extent to which a country's tax system adheres to two important aspects of tax policy: competitiveness and neutrality." (Pomerlau, 2016) This index is regularly calculated for OECD countries (Pomerlau, 2016). This attitude is important especially for comparing tax environment in each country. On the other hand, value of this index cannot be decisive for managers of companies because they usually profit from special attributes of tax legislation. Aggregation itself, although it is standard feature of indexes, predetermines this index mainly for theoretical use. Tax competitiveness index includes ratings of corporation taxation, consumption taxes, property taxes, individual taxes and international taxation (Pomerlau, 2016). The best value reached legislation in Estonia, which is considered as the most competitive in taxes (Pomerlau, 2016).

Values of International Tax Competitiveness Index from year 2016 presents at least one remarkable fact that there are not many countries ranking among tax havens on the top (Pomerlau, 2016). On the other hand, components of this index have higher explanatory power because they focus only on specific attribute related to part of tax legislation. There is no big problem for corporation due to tax planning, when particular tax legislation has relatively higher individual taxes.

For example, Netherlands has achieved first place in part of International Tax Rules, which is in accordance with the assumption, that the Netherlands is very popular as tax haven. Section International Tax Rules includes key parts of international taxation, such as dividend received exemption, capital gains tax, withholding taxes, tax treaties, controlled foreign corporation rules, restriction on eligible countries, interest deduction limitations (Pomerlau, 2016). International taxation is also important due to the potential cash flows between the parent company and its foreign subsidiaries.

Attitude of international organizations is problematic because some of member states are considered as tax havens. On the other hand, the voice of negatively affected countries is strong, so organizations with highly developed members, such as OECD or EU, tend to protect the majority and apply policy against tax havens. Attitude of European Union can be identified through its activities against the Republic of Ireland. EU's view demonstrates case of an agreement between Irish government and American company Apple. Concretely, there has been signed a treatment between mentioned subjects to reduce the tax liability of Apple 
so this treatment has character of tax incentive (European Commission, 2016). This agreement was investigated by European commission and conclusion EU published in 2016. This treatment European commission identified as unlawful state aid to Apple group (European Commission, 2016).

EU study covered tax planning counts with seven basic techniques used within international tax optimization (European Commission, 2016):

- Tax optimization via loans to the investing subsidiary by intermediate company in tax haven (offshore), which is owned by parent company.

- Same as strategy above but instead of an offshore company use an average company based in fictitious EU country.

- This technique is based on first strategy with one specific attribute: loan granted to the subsidiary is classified as equity in the country of an intermediate company.

- Same as strategy three with using an average company based in fictitious EU country.

- Subsidiary pays royalties for licenses and other parts of intellectual property (IP). These payments receive a company based in tax haven.

- Same as strategy above but instead of an offshore company use an average company based in fictitious EU country.

- Based on fifth strategy but IP holding company residents in EU member country, whose legislation includes an IP box.

Overall, all mentioned strategies could be divided into two groups: first with using loans and interest payments (1-4); second group with optimization via royalty payments (5-7). It is necessary to mention that every transaction between two different subjects of one corporation can serve to optimization. European Commission mentions that tax optimization with using of transfer pricing has similar attributes and character as optimization via royalties. That is a reason, why transfer pricing is not expressly delimited in basic strategies.

\section{Measuring Tax Planning}

When it moves to enumeration of amounts of money, which are related to tax haven and tax planning, experts use several ways. First, there is a problem of identification of tax havens. The easiest way is to uncover cash flows of multinational corporations if adequate data is available. One example of institution, which deals with tax havens and tax optimization and has tried to measure activities related to tax planning, is American Congressional Research Service. This institution monitors problematics of taxation from perspective of United States of America, so its researchers do not consider USA to be a tax haven. Their research focuses on activities of American companies, which tend to 
optimize tax liability in the USA. Only concrete data can reveal how much multinationals companies use tax havens. On the other hand, it is difficult to recognize, which operation belongs to tax optimization and which is relevant economic transaction within corporation. American Congressional Research Service (CRS) has presented data, which have some explanatory power. The basement of these data is comparison of U.S. company foreign profits in particular country to the level of GDP in this country (Gravelle, 2015). These data for chosen countries presents following table.

Mentioned values in table 1 indicate different status of countries around the world. Profits of international corporations should be distributed equally if there is no tax optimization. Data show that companies have higher profits related to size of country's economy in countries, which are considered as tax havens. This disproportion is evident especially on value for countries with small economy, which specialize on creation of low tax environment. In the case of European tax havens such as Ireland or Netherlands it can be questionable if this economic activity of US companies is really focused on tax planning activities. This relatively simply way of identification of tax havens does not deal with ways of using tax havens, how many corporations use subsidiaries in particular country or concrete tax savings of multinationals.

\section{Tab. 1 Profits of U.S. Controlled Corporations as a Percentage of GDP in chosen countries}

\begin{tabular}{lll}
\hline Country & $\begin{array}{l}\text { Profits of U.S. Controlled } \\
\text { Corporations as a Percentage of } \\
\text { GDP, 2004 }\end{array}$ & $\begin{array}{l}\text { Profits of U.S. Controlled } \\
\text { Corporations as a Percentage of } \\
\text { GDP, 2010 }\end{array}$ \\
\hline Canada & 2.6 & 3.3 \\
Germany & 0.2 & 0.4 \\
Japan & 0.3 & 0.4 \\
Cyprus & 9.8 & 13.6 \\
Ireland & 7.6 & 41.9 \\
Netherlands & 4.6 & 17.1 \\
Luxembourg & 18.2 & 127.0 \\
Bermuda & 645.7 & 1614.0 \\
British Virgin Islands & 354.7 & 1803.7 \\
Cayman Islands & 546.7 & 2065.5 \\
\hline
\end{tabular}

Source: Gravelle, 2015.

Other studies related to American corporations and their use of tax havens provide more detail information. One of them, which has emanated from cooperation of 
several American institutions - Citizens for Tax Justice, Institute on Taxation and Economic Policy and U.S. PIRG Education Fund (Phillips et al., 2016). This study is focused on Fortune 500 companies and their activities in tax havens. The 298 companies from this list have at least one subsidiary in offshore tax haven, so more than half of them (Phillips et al., 2016). Number of multinational corporations with subsidiary in concrete tax haven can provide basic information about relative popularity of countries as tax havens. Data of 500 corporations indicate that the most popular tax havens are Netherlands, Hong Kong and Singapore. Corporations have accumulated there around 2.49 trillion USD and Apple, Inc. has the highest amount of profits in tax havens, concretely 214.9 billion USD offshore (Phillips et al., 2016). Advantage of this attitude consisting in analysing individual corporations is that it can reveal concrete tax savings of corporation and basic information of its tax planning structure. This study offers complex view on how are tax havens used. Limitation is in count of companies included in this study because only part of these 500 companies used tax havens and all of them belong to the biggest companies not only in USA but in the world as well. Largest corporations have specific needs in tax planning so this study covers only their activities.

Matthias Dischinger, Bodo Knoll and Nadine Riedel (2014) have dealt with location of headquarter and its impact on tax planning. They use a simple model that try to explain profit shifting behaviour of multinational corporations (Dischinger et al., 2014). They "estimate a regression model" with fixed effects of profit in certain year of particular subsidiary before taxation so there is an analysis of panel data. (Dischinger et al., 2014). For the key variables, they use "corporate tax rate differential between the considered subsidiary" and parent company (Dischinger et al., 2014). There is one another important variable in the study: dummy variable, which indicates "if the subsidiary is located in a host country with a larger corporate tax rate than in the parent country" (value 1) or not (value 0) (Dischinger et al., 2014). Model also includes control variables and fixed effects. (Dischinger et al., 2014). For the results, when country, where is located headquarter of corporation, provides lower corporate tax rate than countries for subsidiaries, the amount of shifting money is large and "profits are shifted towards the parent firm." (Dischinger et al., 2014) On the other hand, when headquarter is in country with higher tax rate, profits are shifted away from them and in smaller amounts (Dischinger et al., 2014). Every single study is determined by used data and types of firms, which include. This data is related to European multinationals, so it can differ from studies of US multinationals' data. European corporations tend to prefer gather profits in the parent company, according to this study. 
Petr Janský and Alex Prats (2015) have focused on multinational corporations with activities in India. Their analysis of about 1500 corporations indicates that there is a significant difference between behaviour of companies with connection with tax havens and corporations without option to shift profits to low-tax countries (Jánský and Prats, 2015). Their methodology relies on regression and analyzation of three variables: profitability, tax per assets and tax per profits (Jánský and Prats, 2015). Multinationals, which is using tax havens, paid in 2010 " $30.3 \%$ less in taxes per unit of profits" than the other corporation (Jánský and Prats, 2015). This analyzation has importance mainly in the fact that corporations with ability of international tax planning really tend to exploit it and shift profits around the world to reduce tax liability. On the other hand, analyzation is focused on India and corporations operating there so it covers only their activities in tax planning.

Paper from Giorgia Maffini (2009) has a broader scope than two mentioned above because it includes corporations with headquarters in 15 countries. To the beginning of this study belongs a statistic data of how many subsidiaries have multinationals in predetermined tax havens. Most popular tax havens are Switzerland, Singapore and Ireland. Data sample from this study shows that corporations tend to use larger tax havens than smaller e.g. Caribbean islands. Another important finding from basic data analysis is that mainly larger corporations found subsidiaries in tax havens (Maffini, 2009). This study works with a marginal effective tax rate and their change related to ability of using a subsidiary in tax haven (Maffini, 2009). This model includes "a time-variant indicator for tax haven operations" and also "the difference generalised method of moments (GMM-diff) estimator." (Maffini, 2009) "The GMM-diff controls for unobservable group fixed effects, and at the same time it deals with the likely correlation of unobservable shocks with the first-difference of the lagged dependent variable of other regressors." (Maffini, 2009) Conclusions show that "the marginal ETR of a corporate group with tax haven subsidiaries is about one percentage point lower than groups without low-tax offshore operations." (Maffini, 2009) From perspective of location of headquarter conclusions bring important fact, that "companies headquartered in the United States are characterised by the highest marginal ETR." (Maffini, 2009)

Katharina Schulte Sasse, Martin Thomsen and Christoph Watrin (2017) deal with data from European corporations and their activities connected with tax planning. (Schulte Sasse et al., 2017) They examine how number of tax haven subsidiaries influences "GAAP effective tax rate" of corporation and its tax planning. They use regression of "the ratio of total tax expense divided by pretax accounting income" with dummy variables expressing the number of tax haven subsidiaries of particular multinational. (Schulte Sasse et al., 2017) Other independent variables 
are ROA; leverage; size; number of subsidiaries; number of countries where corporation has a subsidiary; property, plant and equipment of firm, intangible assets and all important fixed effects (Schulte Sasse et al., 2017) "The findings suggest that the more tax haven subsidiaries a corporate group owns, the more tax avoidance is conducted, and vice versa." (Schulte Sasse et al., 2017) This conclusion can be explained in two different ways: first consider that these subsidiaries are founded for tax planning purposes; second way assumes that corporations use their subsidiaries, which are founded in tax havens originally only for regular business purposes, for tax planning. Either way, this study illustrated that multinational corporations use their available channels to tax planning and to reduce their effective tax rates.

Study from Francisco J. Delgado, Elena Fernandez-Rodriguez and Antonio Martinez-Arias (2014) finds determinants of tax rates of European companies. More specifically, they research relationship between effective tax rate and specific attributes of companies using data from database Compustat (Delgado et al., 2014). They use quantile regression with effective tax rate as a dependent variable and mentioned attributes as size, leverage, capital intensity, inventory intensity, ROA, statutory tax rate and several dummy variables to distinguish countries, years and sectors (Delgado et al., 2014). Their main conclusions are following: "for companies with lower ETRs, the most influential variables are size, inventory intensity and profitability, whereas for the companies with the highest fiscal pressure the debt is the most important determining factor." (Delgado et al., 2014) These findings are important for managers and for governments, too, because detection of main determinants of effective tax rate help both sides in decision-making.

Kevin S. Markle with Douglas A. Shackelford (2014) have focused on effective tax rates of multinational corporations and how influence this effective tax rate location of headquarter. They have studied data of 9022 corporations from 87 countries (Markle and Shackelford, 2014). They "use the pooled, cross-sectional regression equation" with effective tax rate as dependent variable and independent variables for country, industry, year (Markle and Shackelford, 2014). They adopt also some changes to this model to identify more about tax planning (Markle and Shackelford, 2014). Overall, their conclusions highlight significant difference between effective tax rates of multinationals according to their location of headquarter (Markle and Shackelford, 2014). "For example, establishing headquarters in Japan, rather than Singapore, results in a 17 percentage point increase in a firm's ETR." (Markle and Shackelford, 2014) According to results of this study, there are similar results for multinational corporations based in USA (Markle and Shackelford, 2014). These remarks confirm importance of tax havens without distinction, whether corporation uses small Caribbean tax haven or high- 
developed European country with lower tax rate (or special regime). Another important remark is related to starting a tax planning. Effective tax rate of particular corporation decreases, when it sets up a first tax haven subsidiary (Markle and Shackelford, 2014). This remark shows that tax havens and operations related to them have impact on tax liabilities of corporations.

Another study focusing on effective tax rates of corporations is paper from Scott D. Dyreng, Michelle Hanlon, Edward L. Maydew and Jacob R. Thornock (2016). They have investigated changes of cash effective tax rates in past 25 years (Dyreng et al., 2016). They have used data from over 54000 United States firms (Dyreng et al., 2016). They apply regression of effective tax rate first only on time, then added other factors (Dyreng et al., 2016). These experts have found out that effective tax rates of U.S. corporations have decreased by 10 percentage points over the 25 years (Dyreng et al., 2016). Their analysis also refutes advantage of multinational corporations in tax planning (Dyreng et al., 2016). Domestic companies show the same decreasing in their effective tax rates as multinationals (Dyreng et al., 2016). This remark is important to perception of tax planning because the ability of tax optimization in time related to this data does not depend on foreign involvement of company. This study is targeting only U.S. companies but the benefit of their conclusion is that it provides view on development in level of effective tax rates.

Morten Bennedsen and Stefan Zeume's "provides novel evidence that corporate tax haven activities are partly driven by private motives of managers and/or controlling owners that extend beyond pure tax saving motives." (Bennedsen and Zeume, 2015) Their study focuses on tax havens and tax optimization from the perspective of value of firms, in which are interested in owners. They use regression for identification of factors that affect value of firms (Bennedsen and Zeume, 2015). Mentioned value of firm is important especially for minor shareholders because they are not able to determine tax-planning activities.

\section{Discussion and Conclusion}

International tax planning belongs to one of the usual ways to optimize tax liability of companies. For identification of countries, which can be considered as tax haven, is important, beside to study tax legislation of countries, to monitor cash flows of multinational corporations. Unusually high amount of profit by subsidiary of corporation in certain country can indicate tax optimization flows. By unusually high profit can be considered profit, which is significantly higher than in similar subsidiary in different country taking into account size of the economy or number of employees of subsidiary. This evaluation of generating profit can reveal tax planning whether they use transfer pricing, IP box or another 
profit shifting activity. On the other hand, locations of profits cannot show real enumeration of tax saving for corporations, they only can provide basic information about extent of profit shifting.

For the showing real differences in taxation related to tax planning studies should be focused on tax liabilities of corporations around the world. Simple comparison of statutory tax rates in countries, where multinational corporations operate, does not show real differences in taxation. Better solution is to compare effective tax rates of corporations, which show real part of profits to identify differences between tax liabilities. Effective tax rates include special tax regimes or tax incentives, which are usually related just for global corporations. Important data sources are databases of companies with information from financial statements and information about ownership structure. Frequently used method is the analysis of panel data using regression with fixed effects.

Mentioned studies and papers show that multinational corporations transfer their profits within group. Location of parent company and its subsidiaries belongs to one of the most important factors within selected studies. Their conclusions show, that significant difference between effective tax rates according to location of taxation and location of headquarter influences tax planning activities. European firms tend to prefer profit shifting towards low-tax countries, especially when there is a headquarter of the corporation (Dischinger et al., 2014). Corporations based in USA have higher effective tax rates than in the most of other countries (Maffini, 2009; Markle and Shackelford, 2014). The possibility of reducing effective tax rate of corporation by using tax havens is shown by Jánský and Prats (2015) and Maffini (2009). There is also important, how many tax haven subsidiaries the corporation has: corporation with more tax haven subsidiaries tend to extensive tax planning (Schulte Sasse et al., 2017). On the other hand, Dyreng et al. (2016) focusing on US companies show that there is no significant disadvantage in reducing of effective tax rate for domestic firms.

Multinationals tend to profit shifting more, when one of the subsidiaries has significantly lower effective tax rate than the others. Overall it means, that groups (respectively their managers) are sensitive to the effective tax rate differential caused by different locations of subsidiaries. More subsidiaries mean more opportunities to shift profits and to lower effective tax rate of the whole group. When the group enters a tax haven, possibility of reducing tax costs is even higher. There is an important role of tax haven for US companies because they have one of the highest effective tax rates. Differences of legislation in EU countries provide more flexible space to tax planning activities. For the concrete countries, often used territories for reduction of the effective tax rate are the Netherlands and Luxembourg. 
Real savings for multinational companies depend on profits and, of course, on the differences between effective tax rates. There can be seen one of the limitations of selected studies because they deal with effective tax rate, which is a relative indicator, and do not provide any information about amount of money which companies really save. On the other hand, analysation of effective tax rate is still the best solution when large set of data is analysed. Some studies deal with features of companies, for example with their size. Bigger companies serve more markets so they can have more subsidiaries also in tax havens even if they do not practice tax planning activities in a bigger amount.

Issue related to mentioned studies is how to identify or define tax havens. Lower effective tax rate does not mean that certain country is a tax haven and vice versa. If the study is based on sort of tax haven list, this problem is even more significant. Questionable is also attitude, when multinational companies are judged by numbers of tax haven subsidiaries. Determination of group of tax haven has impact on interpretation of the results. US view on identification of tax havens differs from the European view and some countries are considered as tax haven only by one from that sides, so any comparison is difficult.

Studies from selected papers do not provide any information about connection between field of the company and certain country. Legislation of countries can be focused on better taxation conditions for different types of companies. Knowledge about fact, in which country companies from certain field concentrate their profits, would be beneficial.

All mentioned studies use one of the business databases (such as Amadeus, Orbis or Compustat) for data acquisition. These data usually include companies from several countries. One issue can be seen in disproportion of amounts and features of companies operating in different countries. Financial statements from some countries or from part of companies do not have to be available, especially when it is an offshore tax haven. Some tax havens offer better conditions in information obligations therefore it is complicated to have relevant data from such countries. Missing values also affect available dataset because some companies must be excluded.

Another issue related to the data is that there are not often available data for several last years because databases collect them from statements from different countries where are applied different conditions on providing information. There is not a big problem but these studies have to be interpreted taking into account this fact. All that means that this sort of study is not helpful for analysis of the effects of new taxation legislation, whether it is information for companies or governments. For the data used, different legislation of selected countries affects financial statements of companies. Accounting legislation can differ from one 
country to another even in the EU. There can be even bigger difference when the study has worldwide dimension.

Some studies include Czech companies, so they also cover their datasets. Companies based in the Czech Republic are often part of multinational concerns, so they can be affected by tax planning activities of their specific parent company. Selected studies do not provide any specific information about tax attractiveness of the Czech Republic, they are focused on behaviour of multinationals overall. The Czech Republic is not on one of the lists of tax havens. Important information related to behaviour of multinationals can be seen in the fact, that they shift profits to optimize tax liability with preferring a headquarter. It means, that if there is a lower effective tax rate for subsidiary (for example in the Czech Republic) than for headquarter of group, group shifts profits less than it is in the opposite situation.

Base comparison of countries via numbers of subsidiaries and parent companies included in study from Dischinger et al. (2014) provide only the information, that there are relatively more subsidiaries than parents companies. This fact is common to most of the smaller countries. Study from Markle and Shackelford (2014), which includes data from multinational companies operating in the Czech Republic, does not show any important role in tax planning for the Czech Republic. Some of the experts, for example Delgado et al. (2014), do not include "new" EU countries in their models so their conclusions cannot be applied on the situation in the Czech Republic.

Taxation conditions in the Czech Republic can be marked as average taking into account results of studies which include data from Czech companies. Multinationals have better options in other countries to avoid paying taxes. On the other hand, mentioned authors do not focus only on Czech companies and their behaviour. As there is only a small part of data related to Czech companies, conclusions related to them cannot be clearly discharged.

Further studies can be aimed at dataset related only to Czech companies and their profit shifting behaviour. This approach can provide relevant view on tax planning activities of Czech companies. From worldwide perspective, the comparison between US multinationals and European corporations could be beneficial and it would be useful to find differences between their tax planning activities and countries that are used for them. 


\section{References}

Bennedsen, M., Zeume, S., 2015. Corporate Tax Havens and Transparency. Asian Finance Association (AsianFA) 2016 Conference. DOI: 10.2139/ssrn.2725577.

Bisnode, 2016. Zájem o daňové ráje letos klesá. 11 October 2016. Bisnode. Available from: <http://www.bisnode.cz/tiskove-zpravy/zajem-o-danove-rajeletos-klesa/>. [19 December 2016].

Delgado, F. J., Fernandez-Rodriguez, E., Martinez-Arias, A., 2014. Effective Tax Rates in Corporate Taxation: a Quantile Regression for the EU. Engineering Economics 25, 487-496. DOI: 10.5755/j01.ee.25.5.4531.

Dischinger, M., Knoll, B., Riedel, N., 2014. The role of headquarters in multinational profit shifting strategies. International Tax and Public Finance 21, 248-271. DOI: 10.1007/s10797-012-9265-5.

Dyreng, S. D., Hanlon, M., Maydew, E. L., Thornock, J. R., 2016. Changes in Corporate Effective Tax Rates Over the Past Twenty-Five Years. Journal of Financial Economics 124, 441-463. DOI: 10.2139/ssrn.2521497.

European Commission, 2015. The Impact of Tax Planning on Forward-Looking Effective Tax Rates. Luxembourg: Publications Office of the European Union, 2016. Available from: <https://ec.europa.eu/taxation_customs/sites/taxation/ files/taxation_paper_64.pdf>. [4 January 2017].

European Commission, 2016. COMMISSION DECISION of 30.8.2016 ON STATE AID SA.38373 (2014/C) (ex 2014/NN) (ex 2014/CP) implemented by Ireland to Apple. Available from: <http://ec.europa.eu/competition/state_aid/cases/ 253200/253200_1851004_666_2.pdf>. [3 January 2017].

Gravelle, J. G., 2015. Congressional Research Service. 15 January 2015. Tax Havens: International Tax Avoidance and Evasion. Available from: <https://www.fas.org/sgp/crs/misc/R40623.pdf>. [9 January 2017].

Jánský, P., Prats, A., 2015. International Profit-Shifting out of Developing Countries and the Role of Tax Havens. Development Policy Review 33, 271-292. DOI: $10.1111 /$ dpr.12113.

Lunder, E. K., Pettit, C. A., 2016. Congressional Research Service. 7 September 2016. FATCA Reporting on U.S. Accounts: Recent Legal Developments. Available from: <https://fas.org/sgp/crs/misc/R44616.pdf〉. [15 April 2017].

Maffini, G., 2009. Oxford University Centre for Business Taxation. September 2009. Tax Haven Activities and the Tax Liabilities of Multinational Groups. Available from: <http://eureka.sbs.ox.ac.uk/3284/1/WP0925.pdf>. [25 January 2017]. 
Jedlička, V.: International Tax Planning: Current State of Knowledge.

Markle, K. S., Shackelford, D. A., 2014. The Impact of Headquarter and Subsidiary Locations on Multinationals' Effective Tax Rates. Tax Policy and the Economy 28, 33-62. DOI: 10.1086/675587.

OECD, 1998. Harmful Tax Competition - An Emerging Global Issue. OECD Publications. Paris, France. Available from: <http://www.keepeek.com/DigitalAsset-Management/oecd/taxation/harmful-tax-competition_9789264162945en\#.WVdmmIjyjIU\#page15>. [25 January 2017]. DOI: 10.1787/9789264162945en.

OECD, 2017. BEPS Actions. Available from: <http://www.oecd.org/tax/bepsabout.htm\#BEPSpackage>. [3 January 2017].

OECD, 2017. Glossary of Tax Terms. Available from: <http://www.oecd.org/ctp/ glossaryoftaxterms.htm>. [15 April 2017].

OECD, 2017. The BEPS Package. Available from: <http://www.oecd.org/tax/ beps/beps-actions.htm>. [3 January 2017].

Phillips, R., Gardner, M., Kitson, K., Robins, A., Surka, M., 2016. Offshore Shell Games 2016. The Use of Offshore Tax Havens by Fortune 500 Companies. Available from: <http://ctj.org/pdf/offshoreshellgames2016.pdf〉. [20 January 2017].

Pomerleau, K., 2014. Foreign Account Tax Compliance Act (FATCA) Goes Into Force Today. 1 July 2014. Tax Foundation. Available from: <https://tax foundation.org/foreign-account-tax-compliance-act-fatca-goes-force-today/> . [15 April 2017].

Pomerleau, K., 2016. International Tax Competitiveness Index 2016. Tax Foundation, Washington.

Schulte S. K., Thomsen, M., Watrin, C., 2017. Do European corporate groups with subsidiaries in tax havens avoid more taxes than others? SSRN Electronic Journal. DOI: 10.2139/ssrn.2897655.

Vartia, L., 2008. How do Taxes Affect Investment and Productivity? An IndustryLevel Analysis of OECD Countries. Working Paper, No. 656, OECD Publishing, Paris. DOI: $10.1787 / 230022721067$.

VK DATA, 2013. Fiscal avalanche in tax haven the Netherlands. 5 April 2013. De Volkskrant Data Blog. Available from: <https://vkdata.wordpress.com/ 2013/04/05/fiscal-avalanche-in-tax-haven-the-netherlands/>. [22 December 2016].

Wiebe, T., 2011. The Benefits of Tax Competition. 25 July 2011. Tax Foundation. Available from: <https://taxfoundation.org/benefits-tax-competition/>. [15 April 2017]. 